\title{
FEMINIST AND STRUCTURAL NARRATOLOGIE AS IDENTITY (RE)-CONFIGURATIONS IN AFRICAN NARRATIVES: A META-CRITICAL EXPOSITION OF LITERARY ARTICLES
}

\author{
Christopher Babatunde Ogunyemi \\ Department of English Studies, Adekunle Ajasin University, Nigeria \\ E-mail: christopher.ogunyemi@aaua.edu.ng
}

APA Citation: Ogunyemi, C. B. (2017). Feminist and structural narratologie as identity (re)configurations in African narratives: A meta-critical exposition of literary articles. English Review: Journal of English Education, 6(1), 21-32. DOI: 10.25134/erjee.v6i1.767.

Received: 21-08-2017

Accepted: 27-10-2017

Published: 01-12-2017

\begin{abstract}
Research in African literature articulated a number of literary and philosophical theories, particularly in the way that they can potentially undo conventional understandings of gender in the Nigerian context. This paper seeks to apply these insights in the form of a critical narratology. Although narratology has a structuralist or formalist orientation, having its theoretical beginning in Saussure's modern linguistics, and like structuralism, aspires to 'scientific' or 'universalist' claims, it, also, examines the way in which narratives affect the way we perceive the world. This paper will attempt to mobilise narratology critically, with the benefit of the insights emerging from various articles, in order to help our understanding of the question of gender and social themes in Nigerian post-colonial literature. Most especially, this paper will visualise the analysis of structural narratology and finally with feminist narratology in order to correct the inadequacies of structural narratology and the suppression of women in texts.
\end{abstract}

Keywords: African literature, feminist narratology, gender identity, structural narratology

\section{INTRODUCTION}

Bal's narratology is a systematic and structural analysis which helps in the ideological study of the commitment of the writer in the narrative (Bal, 1985, p. 10). This means that it helps in understanding the degree of commitment writers underscore in their narratives, thereby showing whether such work is conscious or unconscious of the plight of women, gender and social constructions in art generally. To Fludernik (2009) narratology in this context can identify gender and its various forms in the narrative text showing what constitutes traditional narratives and the instruments of analysis and interpretations which could be applied to explain its framework in narrative form.

To begin with, narratology is defined as the theory and the study of narratives (Bal, 1985 , p. 3, Fludernik, 2009, p. 2; Genette,
1980, p. 3). Genette's narratological works aid the German and Anglo-Saxon literary tradition and it sheds more light to the understanding of the narratological criticism in divergent ways. This goes to demonstrate that, 'narrative does not represent real or fictive story, it recounts it, that is, it signifies it by means of language.

Therefore, there is no place to imitate the narrative. There are simply varying degrees of diegesis, narrative moods, mimesis and every text discloses traces of narration' (Genette, 1980, pp. 42-43). Likewise, narratology helps in the understanding of the context of production as fundamental element of the narrative. That is, it could help readers in clearly discerning the content of the narrative because some of the experiences discussed in it were already known to them. For Fludernik, narratology is a genre which describes constant 
variables and combinations typical of narrative and to clarify how these characteristics of narrative texts connect to the framework of theoretical models (Fludernik, 2009, p. 3). Narratology views narrative structure and the way it affects societal perceptions is reexamined. In principle, narratology can refer to any systematic study of narratives; although in practice, the application of narratology could be rather restricted to the narrative. This is because the way this affects societal's views that it is applied structurally to the study, criticism and understanding of male autobiographical narratives and the question of gender in Nigeria.

\section{Narratology and its trends in narrative art \\ 'Narratology' as a word simply means 'narratologie' which Tzvetan Todorov (1989) in his Grammaire du Decameron forms has been subsequently and continuously used and applied by many writers to different areas and peroids in literature. Although some references may be traced back to the} Aristotle's classic Poetics, modern discourse in the enquiry and interest in narratology is believed to commence with VIadimir Prop, the Russian formalist who wrote Morphology of the Folktale in 1928. Looking at the origin of the work, narratology has a strong relevance and affiliation with the structuralist interest in a system of formed description that could be analysed in any narrative work of art.

According to Culler (1981), different aspects of narratology could be found in any narrative work. Although Culler (1981) observes that the distinction in narratology is mainly suggested by the Russian formalists who used both

Fabula and Sjuzhetas a successive elements in narrative. These successive elements have also been perceived as the same dichotomy, but they would be discussed in relation to the narrative act in the commentary as it advances. For example the use of (historie /recit, story/plot) in the text is a demonstration of this dichotomy. (The Pursuit of Signs, 1981, p. 13). In other words, for any work to be recognised as narratological or otherwise may have much more to do with other forms of narrative, such as works in autobiographical narratives, stories, and the sociology of language.

According to Labov (2006, p. 190), 'narratology examines conversional analysis and discourse analysis which examines the course of frequent and spontaneous verbal interaction in the work of art'. However, constituent narrative structure could be included in the interpretation of male autobiographical narratives. Based on the above, it is essential and extremely important to demonstrate that narratology could enable readers and also critics to critically visualise the content of the narrative, the structure of the autobiographical writings and genderized writings in any text, their cultural artefacts and the movement of time and space in their narrative forms could be examined as well.

Autobiographical writings, genderized writings and other narratives sometimes demonstrate popular culture about the people beginning from their personal lives to their public functioning and finally in the expression of their civic responsibilities in different societies. Roland Barthes' originality in this discourse provides another way of analysing the narrative plot in art. He refuses to be limited by traditional factors which hinder and reduces the understanding of the concept of narratology in any literary art as well. Similarly, Nwachukwu-Agbada (2003) investigates the dynamics of autobiographical writings by asserting that these works discuss ideas which are spread across some periods of time in human history. His conception is based on the environment and 'the result is that practically all the Africa literary autobiographies are public gestures which are derived from a personal struggle with life and agents on the way of psychic, economic, material individual and national fulfilment' (Nwachukwu-Agbada, 2003, p. 103). To him, a series of issues which African autobiographical narratives examine, demonstrate different aspects of discourse in narratology. Nigerian autobiographies cannot be treated in isolation because they incorporate 
various aspects of Nigerian expressions which were also of concern to narratologists (Nwachukwu-Agbada, 1987, p. 97). Essentially, it could also help in the understanding of different constructions of gender and identity in Nigerian literature and society because some writers in Nigeria see gender as display or as performance or an act which could be seen in some of the works coming out of the Nigerian literary environments. Some critics are interested in critiquing different types of narratives because they show how some writers demonstrate gender configurations which sparked various reactions among people (see West \& Garcia, 1988, p. 14; Zimmerman \& West, 1975, p. 157; Lucal 1999, p. 19; \& Golfman, 1957, p. 22).

To Henry MacDonald (1988) narratology can be traditionally projected as the story of narrative fiction which examines actions and their articulated meanings (MacDonald, 1988, p. 1). He goes on to observe that narratology visualizes the narrative presentation of the story using readers' encounters. The story is perceived as a distinct part of the presentation and also constitutes a constructed tale. Epstein (1988) demonstrates that it examines the interpretation of discoursein the text, and such re-interpretation could be 'twice-told all telling ultimately retellings' (Epstein, 1988, p. 230). This means that research in narratology is could be regarded as an effort that is both prescriptive and descriptive in nature. In another development, Epstein also remarks that research in narratology may be socially different or altered' which means that discourses are not usually permanent' in all situations.

A clearer insight to the understanding of narratology and feminist scholarship is given by Lanser (1986) in her essay which is entitled: 'Toward a Feminist Narratology'. This essay critically examined that over the years, structuralist narratology has removed interest and attention away from women studies and gender criticisms; other feminist insights have, therefore, been grossly overlooked by this narratological school as well. In the real sense of the matter and to remove restrictions, narratology is a discipline which is virtually applied to all fields and to all genres. It is basically a way of perceiving texts by both men and women using a variety ways of new analysis (p. 674). However, she probes further that her desire in the aforementioned essay is to re-examine the contributions of structural narratology to feminism, women criticism and the projection of women in literature. Though narratology contributed considerably to the reconfiguration of women in narrative, there are some limitations to this because not until recently gender concerns have not been fully explored by narratology. Therefore, most narratologists treat issues relating to masculinity in male texts which had been in analysis over the years. The projection of male formulations in some texts by most narratologist sometimes makes narratological study difficult for female feminist. In Wisdom and Age in Chinua Achebe's Things Fall Apart (1958) there is a deliberate treatment of male dominance under the auspices of wisdom in relation to age without considering any characteristic feature of women who also constitute the African literary ideologue. This is what Lanser means by a deliberate attempt to use narratology within the structuralist perspective as instruments of oppression and suppression of women in their space.

\section{Structural narratology and its inadequacies}

In order to remove the inadequacies of narratology in the understanding of women writing, feminism, plot and the question of gender in literature, feminist narratolgy reconfigures, re-evaluates and re-traces the portrayal of women and identity in women writings. It challenges the stereotypic projection of women in narratives and suggests a new direction which reverses inferior basis for a proper projection of women, gender and identity in the plot and language of texts. By so doing, she submits that 'the major impact of feminism on narratology, will be to raise new questions, to add to the narratologial 
distinctions that already exists. To probe further, feminist critic attempts to reconcile the way and manner language and signs have been used by structural narratologists in their analysis to suppress women representation in fiction and in other writings because these critics have mostly been one sided in their analyses. The essence is for critics and narratologists for find the usefulness of narrative, content and context of the story, the proper presentation of the characher: male or female and their relevance to gender relations. Similarly, feminist narratology raises some questions which show that the standard plot discussed by narratologists do not really conform to the conventional norm by not explaining some fundamental features of women in some selected texts. This is to denote that structural narratology is yet to provide the most adequate distinction of story and plot. The need to shift attention to feminist narratology becomes expedient because it encourages unbiased criticism of literature and the proper projection of the real image of the woman and the real re-configuration of identity and gender in texts.

\section{Feminist narratology}

Feminist narratology is an important aspect of narratology which could deconstruct narrative and explain some ambiguities in male writings and multiplicities of meanings and interpretations of texts ascribed to them. This is an aspect of narratology which could help to correct patriarchal stereotypes and ethnocentric views in narrative works (Bal, 1985, p. 12), particularly in autobiographical works and in other fictional works. Through the reinterpretation of the narrative text, there is a need to really determine the major issues in the story in order to ascertain if those discussed preoccupations are culturally determined in the plot of the story. It is, therefore, pertinent to demonstrate how narratology helps in the understanding of gender, identity and social themes in Nigerian post-colonial literature. Post-colonial writers in Nigeria incorporate gender configuration, power relations and the portrayal of women as embodiments of their narrative arts. Likewise, these writers in Nigeria assigned various roles to women and men in their narratives which give some concerns to critics and readers alike. The application of narratology to narratives explains some complex gender and identity ambiguities which are the foregrounding issues in some male writings. Example of such ambiguities in the narrative is well delineated when narratology is applied to the narrative, such as the creation of male subject in the work and that of a female object. This situation sometimes calls for reversal in the story where there is a re-construction which allows for the woman to take the lead role and become the female hero in the narrative.

However, when a narratologist decides to examine the body of knowledge in the narrative, the significance of female body and how it interprets the social milieu could be underscored and this situation could aid the understanding of gender and identity. This is because the power of the narrator and what $\mathrm{s} / \mathrm{he}$ represents in literature could be reinterpreted and this informs the reason why de Lauretis (1984, p. 24) asserts that 'women are heroes of their own stories'. In the process of writing back and correcting some narrative anomalies in masculine writings, she brings in new innovations and concepts which help to re-configure society in the appropriate way. She pushes this further because this type of narratology exemplifies how stories use characterisation to delineate societal problems which women are actively involved in and how feminist narratologists attempt to reverse masculine positions in narratives in order to achieve social and cultural transformation for egalitarian society.

In the feminist context, narrative systematises the text in order to potentially free narratology from ethnocentric, identity representation and patriarchal configurations which are mostly discussed in many male writings in Africa. By so doing, the narrative would not be biased and central to the promotion of masculine tendencies in 
narratives. Similarly, Bal (1985, p. 22) and Fludernik (2009, p. 15) agree that narratology itself is central to the structuring system of binary opposition because it gives room for the narrative art to examine its oppositions and ambiguities. This means that there is a universal appeal in a narrative when it examines the culture of a group of people by attempting a binary resolution in order to appeal to feminist consciousness. In addition, to demonstrate and elaborate the usefulness of narratology, critics often apply this to some literary ideologies in order to comprehend literary concepts so that the benefits of narratology and its refinements could be properly internalised in the texts. Likewise, to properly comprehend post-colonial issues in literature, such as social themes, the portrayal of women, gender construction and identity representation, narratology sometimes produces an adequate framework for the understanding of these concepts in the narrative. Dwivedi et al. (2010, p. 6) uphold the aforementioned and submit that 'the condition of post-coloniality has been variously comprehended through metanarratives of fall and decline, progress, enlightenment, and the attainment of civilization and democracy. However, narratives produced in the historical phase explain related works of fiction, travelogues and autobiographical accounts awakening and liberation'. Consequently, the application of narratology in Nigeria could fill the lacuna in the portrayal of women in autobiographical and other gendered writings. It could also explain the configuration of gender, identity representation and the re-interpretation of social themes and masculinities in Nigerian post-colonial literature and history.

\section{Narratology and the interpretation of texts}

In 'Genderization in Male Autobiographical Narratives in Nigeria' (2011), narratology is used to interpret some activities of characters and events in Nigerian social and political space through narratives which centre on various experiences around men and women.
The application of meta-narrative interpretation in narratology illuminates the message and portrays a clearer image for the reader and the critic. What this implies is that the primary object of interpretation is the narrative act of telling the story. 'The story' expresses the purpose of criticism. Logically speaking, both the content and the telling of the story are narrative acts, which are some preoccupations of narratology. Similarly, in the article, Wisdom and Age in Chinua Achebe's Things Fall Apart (1958), narratology is discussed andwisdom is used by the culture as a model for measuring the knowledge of men and women in the patriarchal Nigerian and Igbo society. However, it re-invokes masculine importance using Okonkwo the lead character as emulation for all in society. This gendered classification of wisdom and age is done at the expense of feminity and it informs a psychological tool which is used to further suppress women. This situation sometimes explains the distinction between story and narrative act which is commonly conceptualized by narratologists as well. This distinction according to McDonald is traditional because it does not provide any other means of identical formulations in the work of art (Macdonald, 1988: 4). The analysis is dynamic because autobiographical and gendered narratives are complex phenomena which express series of formulations about 'self' in Nigerian literature and it is a portrayal of gendered feelings as well.

Similarly, studies in these aforementioned articles blend narratological theory with autobiographical approach and with gender theory in order to show various relationships and ambiguities of these gendered writers. The need for the application of the trio is to bring out social relevance in Nigeria and in Africa. To portray this, other researchers have used many approaches to examine narratives in their own ways. For example, Strauss and Corbin (1998) applied the analytic strategic approach in their literary application of art. Eyoh (2003), Raditlhalo (2003), and Chukwuma (1990) use the sociological approach as suitable critical 
framework, which clearly illuminates the position of characterization and how it becomes relevant to the contemporary society in autobiographical and critical analysis. The first aim is to identify elements of existing scholarly definitions which support autobiographical narratives and then relate the approach to narratology.

However, both 'Genderization in Male Autobiographical Narratives in Nigeria' (2011), and Wisdom and Age in Chinua Achebe's Things Fall Apart' (1958) apply narratological tenets to the analysis of texts and criticisms of the social themes in the postcolonial Nigerian experience. To start with the 'Genderization in Male Autobiographical Narratives' (2011) most male autobiographical works presented in the article portray some deliberate and inveterate marginalization of the African woman by patriarchy. Likewise, the article 'Wisdom and Age' is a cognitive examination of the mental state of men which presents the Nigerian male culture and how these male writers, particularly in Nigeria were using their works to over-exemplify masculinity without recourse to females who are part of such society. However, writings in this regard loose the social construction because it does not enforce the performative aspect of art. Writing should be able to reinterpret and re-configure the cultural phenomenon in contemporary setting in order to prepare a suitable environment for both men and women in relation to their social and cultural perspectives.

In 'Genderization...' (2011) while women are frequently exposed to psychological, physical and social violence. 'Wisdom and Age..' (2010) is a psychological and cognitive empowerment of masculine tenets at the expense of feminity. According to this article, 'it is evident that Okonkwo, despite his tender age applies the instrument of wisdom to changing his class for good believing in "solid personal achievements" is akin to wisdom. Okonkwo uses his wisdom to address strength, energy disposition and quest for new innovation. Because Okonkwo (2010, p. 123) positions himself in a wise dimension, he grows from strength to strength'.

Consequently, this leads to sexual and cultural relegation of women through narratives which their male counterparts evoked using the autobiographical and psychological works as instruments of portrayal of themes and subject matters. These papers combine previous research on women and some practical and critical expressions about their feelings to delineate genderization in selected male narratives which propel masculinity in Nigeria. To further explain this, it is pertinent to note that most contemporary societies and cultures in Nigeria are male dominated in many areas. So these societies and cultures go further to create beliefs system, economic exploitation of Nigerian women and other forms of injustices which limit the place of women in literature and society. Consequently, the work calls for the need to embark upon a socio-politicoeconomic re-configuration and cultural integration for African and Nigerian development in the aspects of developing literature and making people feel the positive impact of globalization in order to make some meaningful contributions from the African woman when the cultural trends are reversed.

As earlier observed, male writers have frequently used their works to elevate themselves beyond normal proportion in Nigeria. In essence the elevation of self by male autobiographical narratives has been seen by Raditlhalo (2003, p. 16) as a recurring problem confronting the proper explanation of the roles of gender in contemporary African society. Similarly, Okpara (1990, p. 17) asserts that the marginalization of women by male chauvinistic writers affects the place of women in African literature. This has become the 'usual' trend in male-dominated literature in Africa; and it explains more situations in gender and social themes in the post-colonial Nigeria. She further observes that although the African woman is repressed by the normative patterns of her male-dominated culture, she is well informed of other social and political forces in society which may take precedence 
over sexual politics (Okpara, 1990, p. 18; Chukwuma, 1990, p. 11; Chukwuma, 2004, p. 10). She would rather identify more with the African man in the struggle for social and political freedom despite the domination (Okpara, 1990, p. 158). Although, in the course of identifying with her male counterpart, the autobiographical writer still over-exercises his control over the woman. This makes Chukwuma to remark that the woman is portrayed in various works including the autobiographical narrative as 'a handicapped daughter, wife and mother even when the decisions affect her directly' (Chukwuma, 2004, p. 131). Different works in Nigeria have portrayed this fact which Chukwuma (2004, p. 132) observed and these works have also shown that the most feasible way to bring into the limelight female subjugation in written autobiographies is her economic dependence on men and the social demand that a woman gives all her earnings to the home.

Consequently, in 'Confronting Inequity in Nigerian Social Milieu: Apprehending Class Stratification in Festus Iyayi's Violence' (2013) females have started critiquing and reexamining these male essentialist assumptions which require that they give all their earnings and their efforts to the family. By implication, feminist scholars have also started to develop feminist theory which is based on a theoretical or philosophical analysis of women's liberation politics. This gradually leads to women's studies which emerged to look into different problems confronting the woman and the urgent need for solutions. In the aforementioned articles, feminist politics and women's studies put a spotlight on the inequities between women and men in almost all Nigerian societies. In the West, women campaigned to gain equal rights and opportunities and in the developing world, this was applied to aid them in development. It is imperative to state that there are vast differences between the needs of women in developed nations and their counterparts in developing nations too. According to Butler, there is a need to understand different approaches in the appraisal of the inequalities between men and women and between women in developed and developing economies in order to ascribe roles which are culturally motivated and performative in the realisation of their potentials (Butler, 2013, p. 77).

Therefore, if the needs of women in Nigeria are identified and ascribed, there would be more relevant social functions in the scheme of things in their encounter with their male counterparts.

The above mentioned articles also focus on political and economic inequalities which exist among women and men in Nigeria. These articles discuss the term 'gender' and showcase how some male writers and their cultures make it synonymous with 'women'. It is pertinent to note that it is not until the 1980s that the field of masculinity studies emerged in literary discourse. Masculinity (or men's) studies systematically focused on the construction and the depiction of males as superior phenomenon (Spivak, 1989, p. 223; Spengeman, 1980, p. 27; Smith \& Watson, 2010, p. 56). The mentioned articles further analyse ways in which gender and power operate in the lives of men that develop the masculinity theory. This new field of study has started to highlight the ways in which gender inequalities affect not only women, but also men (Spengeman, 1980, p. 28). More recently, a multidisciplinary field of study has emerged; it examines the cultural representations and the life experience of being male or female. In 'Okotp' Bitek's Song of Lawino: Singing About the Rights of Present African Women' (2014) cultural representation places women as second class citizens. This breads hatred, jealousy and unhealthy rivalry in the family: among children and wives in the case of polygamous setting. This paper expresses the plight of Lawino the oppressed African woman who is handicapped by unbridled competition in the family and the need to satisfy the husband since he now has a new bride. In most parts of Black Africa, women experience such oppressive situation and it culminates into depression and rejection. 
In some other situations, poor men who cannot afford to pay bride price sometimes stay away from marriage while those men who can afford to pay as many go home with new bride every new season. This allows for an analysis of gender for both women and men, and it is used to interrogate the phenomenon in a wider range of disciplines and also in the interrogation of narrative and poetic truth.

\section{Butler's gender performativity and the nexus of relevance}

Butler's gender performance helps in the understanding of truth in order to underscore the nexus of life experience in the areas of social relevance of the woman and also in the development of the contemporary Nigerian and African society. The application of gender theory to poetic and narrative works explains the relationship which exists between the male/female characters and their social functions in the actualisation of the concept of self-narrative in the post-colonial Nigeria. In addition, most novelists in Nigeria use their expressions of narrative and poetic meta-texts to explore the place of feminism, identity and gender in Africa. Examples abound. Chinua Achebe creates the classic character-Okonkwo and entrusts him over every events and activities in Umuofia community. The plot of the novel revolves around him from beginning to the end of the story. In 'Wisdom and Age' (2010) most Nigerian critics applaud the fame and prosperity of Okonkwo by acclaiming this factor through their perceived psychological stream of consciousness. In the article, 'we examine the novel textually by pinpointing some elements of wisdom that was demonstrated by Okonkwo'. The impression created was as if only Okonkwo existed in Umuofia community. In most Okonkwo criticism, critics sometimes genderised other men but women suffer most as a result of the criticism on patriarchy arising in African and Nigerian society. This means that while analysing respondents' responses, most people stood in favour of Okonkwo the supposedly male protagonist of this classic novel, Things
Fall Apart. This expression is expected to show life experience as it is in the original way. It is imperative to note that many scholars have examined various experiences in their own ways, particularly with recourse to life expectations in the post-colonial Nigerian literature which tries to write back to the colonialists. This process of writing back to the centre demonstrates African reactions to colonialism and subsequent post-colonial experiences (see Chukwuma, 2003, p. 12, Okpara 1990, p. 11).

This takes us to the interrogation of social issues in order to further examine the sociopolitical and economic problems ravaging the post-colonial Africa and Nigeria. In 'Living Anonymity: Exile as Motif in Lenrie Peters $\mathrm{He}$ Walks Alone' (2013) most emerging African states suffer the problem of identity and abject poverty. This makes some privilege few attempts to seek a new life by engaging in either collective migration or forced migration. Some could take to permanent exile in order to run away from poverty and inequality which preoccupies most African countries. Most people suffer in a large scale and these experiences could constitute some social themes which the commentary sets out to examine. However, in Nigeria poetry have been used to delineate such themes, such as violence, corruption, gender imposition and economic manipulation in Nigeria. Example of such works include Osundare's 'They too are the Earth' and Soyinka's 'Telephone Conversation' in 'Living Anonymity..'(2013) which demonstrates social problems of exile and psychological intimidation people frequently go through (p. 205). In the paper, themes were examined to show the state of the country and how people react to some of these issues. To be specific, poverty is a theme that is prevalent among men and women in Nigeria because leaders have not been able to judiciously use the country's potentials to develop the people. The paper shows that people were not comfortable with problems of economic breakdown, youth restiveness, unemployment and the emergence of class 
system in most sectors of the economy results in the reason for forced exile and migration.

In this paper, social themes and trends in genderization, attempts were carried out in explaining salient points which constitute the Nigerian experience. This research relies on tripartite theories of narratology, gender theory and autobiographical theories, but most especially relies on gender theory because of the overriding thematic preoccupation of genderisation which is a cut across phenomenon in these articles. The application of gender theory sometimes explains the relationship which exists between male and female in Nigerian culture and it also evaluates the themes of gender and development in African and the Nigerian writings. So far, narratology been the scientific study of the narratives makes references to history and the genderised periods in the analysis of two articles cited above. This narratological position agrees with White when he opines that history helps in the construction of works of art in society. It also explains some ambiguities found in the narrative as to the observation of White when he opines that the twentieth century ushers in a period when history cannot be considered an art or science because a body of literature has created many doubts about the status of history either as science or art. This is to show the complex relationships between history and literature and to further demonstrate how history has aided in the critical understanding of the literary works of art.

For some specific emphasis, and to understand how White handles historical relevance in the narratives, the commentary briefly examines Sjuzhet and Fabula and explains their narratological contents on the narratives with regards to how White handles the historical elements in the narrative. Viktor Shklovsky and Vladimir Propp, Russian formalists were the first to use these terms and ever since then Sjuzhet and Fabula had gained frequency in narratological studies. However, Sjuzhet details the various employments of historical periods in the narrative and roles history plays in the formation of the plot in the narratives. It also explains how history is relevant in narratives and the understanding of the behaviour of human beings as explained in the narrative with its various implications ascribed to it. Likewise, Fabula is the story itself; it examines concurrently the content information in the narrative. Fabula details a chronological order of presentation of the story and enables the reader to follow the story in order to understand the relationships among those narratives troupes, such as plot, character, and characterization. It is pertinent to note that some historical references were carried along in the explanation of those autobiographical and patriarchal writing. This historical references stimulated those current experiences Africans have despite independence had long been gained. The application of Sjuzhet and Fabula would be explored as the commentary progresses.

Through Fabula or the plot structure in most Nigerian narratives, we have been able to see alienation as a social issue and at same time as something which denotes various levels of genderised feelings in most of the cited articles. Alienation could be seen asan aspect of gender performance among people that live in communities. However, Behringer sheds more light on some performances of gender in society. She agrees that 'the doing gender framework explains the freedom men and women pose in creating their own gender, individuals have option as to how they will perform gender, they fundamentally have the ability to craft, mould and at the same time fashion their environments'the way they want it or perceive of it (Behringer, 2008, p. 52). Similarly, most women in Nigeria frequently complain of alienation whenever it is time to be accorded some serious functions, particularly when it has to do with their male counterparts. This situation is evident in some Nigerianclassic novels like Achebe's Things Fall Apart (1958) and in other texts or narratives which set out to demonstrate the performance of masculinity over females in Nigerian society. In Things Fall Apart (1958) 
Achebe creates Okonkwo the main character who is at the centre of his own world. He is loved by his Umuofia people. Being the 'Agu, and the Ebube Dike' of his community meaning, the 'eye', 'the voice', 'the roaring lion' and the strong man of his community, he does not want to be called a woman and a weakling. In Achebe's Igbo culture and indeed most African cultures, women were ascribed as weaklings and second class citizens

(Chukwuma, 2004, p. 19). Okonkwo the male protagonist demonstrates his masculinity by marrying many wives, having many children and taking rash decisions without listening to any counsel from a woman or asking a woman to decide for him in some strategic decisions (Achebe 1958: 70). An example of the rash decision he took was the neglect of one of his wife's admonition against having a hand in the death of Ikemefuna. Ikemefuna was the little boy kept in his custody, and in the course of living together, the boy now calls him a father. Ikemefuna was given to Umuofia people as ransome for the atrocities done to them and he was being prepared for sacrifice so that his blood could appease the Umuofia community.

Furthermore, in most African communities, women have no inheritance; they do not attend family meetings and they are strangers to their families, particularly among Okpodon Clan of Cross River State, the Irun Akoko people of Ondo Sate and the Igbo people of Nigeria among many others where they demonstrate with grandeur the emergence of a male child with pomp and pageantry at the expense of the female child. This situation explains why traditional Tiv man of Benue State in Nigeria will marry many wives so that he could use any of his women to entertain his friends and to satisfy their sexual pleasure at nights when such friends come visiting and he expects such 'friendly gestures' in reciprocation when he visits such friend in future. The culture of using wives to entertain friends cut across some Tiv and Idoma peoples of Nigeria (Chukwuma, 2003, p. 23). It is also acclaimed that some Yorubas and Ijaws would marry many wives to justify their wealth and the number of children they have so that they could be accorded much respect among their peers (Chukwuma, 2003, p. 25). This explains concurrently why some African men would give out their daughters as gifts to strong men in society for marriage. The act of entertaining best friends with the wife is seen by both the Tiv man and some brainwashed women in Benue Nigeria as a preservation of their cultural acts and friendliness since there is a sharing of love together. Ironically, these women are not complaining openly and there is no open protest though there could be sorrow and depression which lead to gender violence. This could probably be the reason why the HIV/AIDS is dominant in Benue State more than any other states in Nigeria (Mwakikagile, 2001, p. 18). This situation sometimes leads to alienation, fear and intimidation among women.

To show this alienation further, the notion behind the creation of 'I' as male metaphor and other forms of social identities separate the man far away from the woman in social contexts. This is demonstrated in the article 'Interrogating Power Relations' (2011) where violence and intimidation of women in society become manifested in many sectors in Nigeria. Women experience high level of suffering in their contacts with males. This could furtherdemonstrate women's social identity and relevance, gender differences and struggle for survival ('Interrogating Power', 2011, p. 307). Furthermore, 'Confronting Inequity' (2013) attempts to show various expressions of readers as they readthrough the post-colonial works emanating from Nigeria. Readers were able to see the level of violence and protest levied on the weak, poor and the hopeless in the article. However, in the readers-response approach; the critic really situates what he detests and how he perceives as the notion of gender in literary works of art. The same situation is true when it comes to the reader of the narrative text. Kafalenos sheds more light on this when she observes that readersresponse approach is an essential narrative art. Therefore, interpretations and causes of 
narrative events are contextual in nature (Kafalenos, 2001, p. 33). Kafalenos is not referring to the message but to the narrator and readers and their perceived interpretations. Also, the way and manner through which critics demonstrate gender equality and other social themes help in re-shaping the postcolonial experience in Nigeria ('Genderization, p. 37).

\section{CONCLUSION}

This paper examined structural narratology, feminist narratology and suggested that in Africa, the instruments of identity; alienation and gender construction have been exemplified in most post-colonial narratives through expression, body language and related actions. With various explications of narratology in delineating gender interpretations, the paper improves on feminist narratology as a most suitable theory which could be modelled with Butler's performativity to showcase relevant discourse about women in future research in African literature.

\section{REFERENCES}

Achebe, C. (1958). Things fall apart. London: William Heinemann Ltd.

Bal, M. (1985). Narratology: Introduction to the theory of narratives. Balzac de Honore: Totonto Press.

Behringer, M. A. (2008). Gender in contemporary literature. New York: May and Baker.

Butler, J. (2013). Ppassing, queering. In Nella Larsen's Psychoanalytic Challenge 1997, Global Literary Theory: An Anthology (p.281). London: Routledge.

Chukwuma, H. (1990). Voices and choices: The feminist dilemma in four African novels. In Ernest N. Emenyonu, Literature and black aesthetics ( $\mathrm{p}$ 131), Ibadan: Heinemann.

Chukwuma, H. (2003). Accents on the African novel (2nd ed.). Port Harcourt: Pearl Publishers.

Chukwuma, H. (2004). Women writing: Feminism and national development in Nigeria (An Inaugural Lecture Series, 35 University of Port Harcourt, February 5).

Culler, J. (1981). The pursuit of signs: Semiotics, literature, deconstruction. Ithaca: Cornell UP.

Dwivedi, D., Henrik, S. N., \& Richard, W. (2010). A book proposal on narratology and ideology: Encounters between narrative theory and postcolonial criticism. New York: York University.
Epstein, C. F. (1988). Deceptive distinction: Sex, gender, and the social order. New Haven: Yale University Press.

Eyoh, L. E. (2003). Socio-political protest and poetic imagination. In Clark- Bekederemo's Poetry. English Studies (April Edition). University Port Harcourt.

Fludernik, M. (2009). An introduction to narratology. London: Routledge.

Genette, G. (1980). Narrative discourse. New York: Cornell University Press.

Iyayi, F. (1979). Violence. London: Longman.

Kafalenos, E. (2001). Not yet knowing: Epistemological effects of deferred and suppressed information in narratives New York. The Psychology of Life Stories Reviews of General Psychology, 5, 100-122.

Labov, W. (2006). The social stratification of English in New York City. Cambridge: Cambridge University Press

Lanser, S. S. (1986). Toward a feminist narratology. In Style 20, 341-363.

Lucal, B. (1999). What it means to be gendered me: Life on the boundaries of a dichotomous gender system. Gender and Society, 13, 781-797.

Mwakikagile, G. (2001). Ethnics politics in Nigeria and Kenya. New York: Nova Science Publication.

Nwachukwu-Agbada, J. O. J. (1987). Protect and faith. In W. Soyinka's Autobiographies, The Literary Half - Yearly.

Nwachukwu- Agbada, J. O. J. (2003). Environment and 'I' of the beholder in African literary autobiographies'. Working Papers. (University of Port Harcount).

Okpara, C. (1990). The foot as metaphor in female dreams: Analysis of Zaynab Alkalis novels' Literature and Black Aesthestics. Ibadan: Heinemann.

Prop, V. (1985). Morphology of the folktales. (1928). Hillsdade, NJ: Lawrence Erlbaum Associates, Inc

Raditlhalo, S. I. (2003). Who am I? The construction of identity in twentieth century south African autobiographical writing in English. (a PhD Dissertation Submitted and Published by the University of Groningen, The Netherlands).

Smith, S., \& Waston, J. (2010). Reading autobiography: A guide for interpreting life narratives, $(2 n d$ ed.). St Paul: University of Minnesota Press.

Spengeman, W. (1980). The forms of autobiography: Episodes in the history of a literary genre. New Haven \& London: Yale University Press

Spivak, G. C. (1989). Feminism and deconstruction: Negotiating an unacknowledged masculinism. In T. Brennan (Eds), Between feminism and psychoanalysis (pp. 206-223). London: Routledge.

Strauss, A., \& Corbin, J. (1998). Basic of qualitative research .Oaks, CA: Sage Publications.

Todorov, T. (1989). Grammaire du decameron. The Hague: Montou. 


\section{Christopher Babatunde Ogunyemi}

Feminist and structural narratologie as identity reconfigurations in African narratives: A meta-critical exposition of literary articles

West, C., \& Garcia, A. (1988). Conversational shift work: A study to tropical 'Transitions between Women and Men'. Social Problems, 35, 55-575.

Zimmerman, D. H., \& West, C. (1975). Sex role, interruptions and silences in conversation. In B.
Thorne and N. Henley (Eds.), Language and sex: Difference and dominance. Rowley, MA: Newbury House. 